\title{
Determination of the Reduced Sulfur Species in the Water of Anoxic Basins
}

\author{
A. V. Dubinin ${ }^{1, *}$, T. P. Demidova ${ }^{1}$, M. N. Rimskaya-Korsakova ${ }^{1}$, \\ L. S. Semilova ${ }^{1}$, O. A. Ocherednik ${ }^{2}$ \\ ${ }^{1}$ Shirshov Institute of Oceanology, Russian Academy of Sciences, Moscow, Russian Federation \\ ${ }^{2}$ South Branch of Shirshov Institute of Oceanology, Russian Academy of Sciences, Gelendzhik, \\ Russian Federation \\ *dubinin_av@mail.ru
}

Introduction. Development of anoxia in marine basins leads to formation of hydrogen sulfide and the intermediate reduced sulfur species - thiosulfate, sulfite, zero-valent sulfur and sulfur of polysulfides. Except for thiosulfate, the data on the other reduced species of sulfur in the Black Sea water are scarce. The thiosulfate concentration in the papers of different authors varies from 20 to $40 \mu \mathrm{M}$; and it can be a consequence of hydrogen sulfide oxidation during sampling and analyzing.

Data and methods. The previously proposed (by I. I. Volkov and N. N. Zhabina) method for determining the sulfur reduced species (sulfite + thiosulfate, zero-valent sulfur + sulfur of polysulfides) in the anaerobic basins' water has been re-evaluated and developed. Addition of suspension $\mathrm{Zn}_{2}(\mathrm{OH})_{2} \mathrm{CO}_{3}$ to a seawater sample destructs polysulfides and transfers the elemental sulfur to precipitation. The elemental sulfur, sulfur polysulfides and sulfides are separated from the sum of thiosulfate and sulfite by filtration. To analyze the reduced species of sulfur, we applied their reduction to hydrogen sulfide which is determined spectrophotometrically after its distillation in the argon stream and precipitation as $\mathrm{ZnS}$.

Results. The results of determining the sulfur species were tested by analyzing $2 \%$ solutions of $\mathrm{NaCl}$ with the introduced contents of thiosulfate $(0.5-1.5 \mu \mathrm{mol})$, sulfite $(<1 \mu \mathrm{mol})$, elemental sulfur $(<1 \mu \mathrm{mol})$ against the background of much higher concentrations of hydrogen sulfide $(60 \mu \mathrm{mol})$. Such ratios of concentrations of the sulfur reduced species and hydrogen sulfide are found in the Black Sea water.

Discussion and conclusion. It is shown that the proposed method correctly reflects presence of the reduced species of sulfur in the solutions. To analyze the sulfur species, the Niskin bottles are necessarily filled with the inert gas and the samples are filtered in the inert atmosphere. The method for determining the sulfur reduced species is highly sensitive. The detection limit for $\left(\mathrm{S}_{2} \mathrm{O}_{3}^{2-}+\mathrm{SO}_{3}^{2-}\right)$ is $0.03 \mu \mathrm{M}$, for $\left(\mathrm{S}^{0}+\mathrm{S}^{0}\right.$ polysulfide) is $0.02 \mu \mathrm{M}$ and for sulfide sulfur $-0.01 \mu \mathrm{M}$.

Keywords: thiosulfate, sulfite, zero-valent sulfur, polysulfides, hydrogen sulfide, method of determination, detection limit, the Black Sea.

Acknowledgements: the research is carried out within the framework of the state task of the Institute of Oceanology, RAS (theme No. 0149-2018-0015) at the partial support of RFBR (project No. 18-05-00580).

For citation: Dubinin, A.V., Demidova, T.P., Rimskaya-Korsakova, M.N., Semilova, L.S. and Ocherednik, O.A., 2019. Determination of the Reduced Sulfur Species in the Water of Anoxic Basins. Physical Oceanography, [e-journal] 26(1), pp. 32-46. doi:10.22449/1573-160X-2019-1-32-46

DOI: $10.22449 / 1573-160 \mathrm{X}-2019-1-32-46$

(C) 2019, A. V. Dubinin, T. P. Demidova, M. N. Rimskaya-Korsakova, L. S. Semilova, O. A. Ocherednik (C) 2019, Physical Oceanography

\section{Introduction}

Microbial reduction of sulfates due to the organic matter oxidation leads to the appearance of hydrogen sulfide in anaerobic basins. Apart hydrogen sulfide, other reduced forms of sulfur (the intermediate ones), mainly represented by sulfite 
$\left(\mathrm{SO}_{3}^{2-}\right)$, thiosulfate $\left(\mathrm{S}_{2} \mathrm{O}_{3}^{2-}\right)$, zero-valent sulfur $\left(\mathrm{S}^{0}\right)$ and polysulfides $\left(\mathrm{S}_{\mathrm{n}}^{2-}\right)$ [1-9] were found in water. The available data for the anaerobic waters of the Black Sea and the Cariaco Basin show that the content of intermediate reduced forms of sulfur can be 2-3 orders of magnitude lower than the content of hydrogen sulfide. Sulfite in the hydrogen sulfide presence in water is reactive with it and turns into thiosulfate [10]. High contents of zero-valent sulfur $\left(S^{0}\right)$ were found in the near Bosporus area in the Black Sea, where the oxygen-containing waters of the lower Bosporus current penetrate into the hydrogen sulfide waters of the anaerobic zone of the Black Sea [11]. The accumulation of zero-valent sulfur was also found below the horizon of the hydrogen sulfide disappearance in the upper part of the anaerobic zone [3, 4]. In the presence of hydrogen sulfide and the products of its dissociation in the anaerobic zone, zero-valent sulfur is reactive with them forming polysulfides $\left(S_{n}^{2-}\right)$ [1, 2 and 9].

Content of thiosulfate combined with sulfite was previously determined by titration of excess iodine in the filtrate after precipitation of hydrogen sulfide [12, 13]. Dissolved inorganic forms of sulfur in the Black Sea water were measured applying method of voltammetry [3], and spectrophotometric method after filtration and cyanolysis was used for elemental sulfur [4]. High performance liquid chromatography allowed determining the concentrations of thiosulfate and sulfite separately in the entire water column of the Black Sea for the first time [5]. This method, in one modification or another, is widely used today to study these compounds in anaerobic waters [6-9].

In 1990, a method for determining hydrogen sulfide, the sum of zero-valent sulfur and polysulfides, as well as the sum of thiosulfate and sulfite from a single water sample in the shipboard laboratory was proposed $[14,15]$. It can be applied to determine the content of the listed forms of sulfur with a detection limit of about $1 \mu \mathrm{g} \mathrm{S}$. The main poblem of this method is the inability to determine the sulfite and thiosulfate separately and to divide sulfur of polysulfides from zero-valent sulfur. Despite these shortcomings, the method has a number of undoubted advantages. It has a high sensitivity, can be used in the ship's conditions and obtain data already during a cruise and be used to study the isotopic composition of sulfur of reduced forms [16]. 


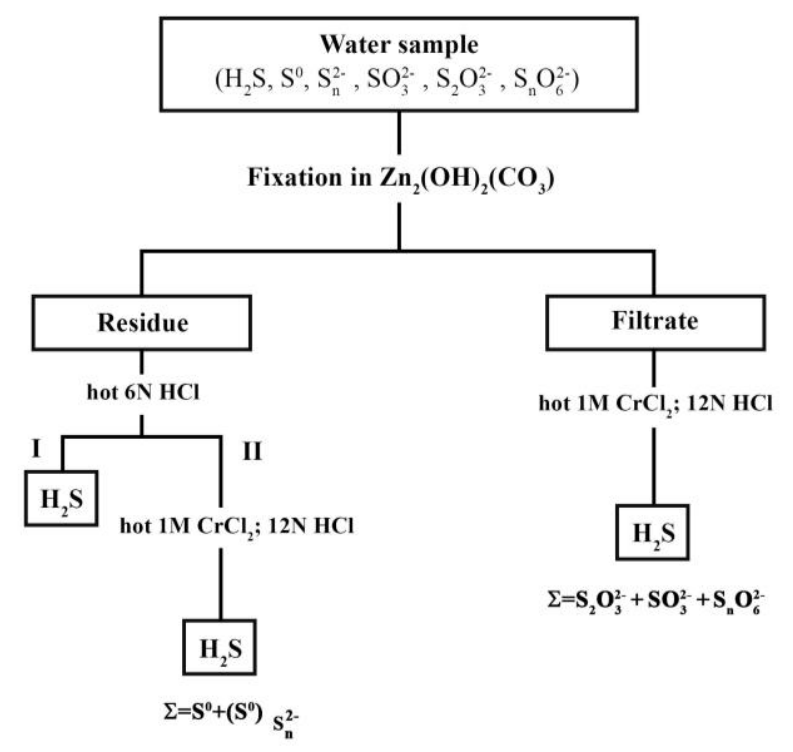

F i g. 1. Scheme of analyzing. Modified version of Fig. 2 from [16, p. 62]

The method provides for the separation of the sulfur forms after precipitation of hydrogen sulfide, polysulfides and zero-valent sulfur with $\mathrm{Zn}_{2}(\mathrm{OH})_{2} \mathrm{CO}_{3}$ suspension (Fig. 1). Thiosulfate and sulfite remain in the filtrate. In [14, 15], the authors do not present data on the stability of thiosulfate and sulfite in solutions with $\mathrm{Zn}_{2}(\mathrm{OH})_{2} \mathrm{CO}_{3}$ suspension, the achievement of completeness of the analysis, the limits of detection of sulfur forms in seawater solutions and the reproducibility of the method. There is also no data on the way how the Niskin bottle filled with the air or inert gas when sampling water, as well as the filtration of samples in the air (according to the recommendations of the authors), affect the experiment results. In addition, the degree of complete removal of sulfide from the sample and its effect on the determination of thiosulfate and zero-valent sulfur remained unclear.

The present paper gives the results of the study of reduced forms of sulfur, carried out using our corrected methods for their determination. Changes in the methodology were made based on experimental data. The influence on the results of the analysis of the sulfur forms for sampling water from the Niskin bottle after its filling with the air or argon is considered. Filtration to separate $\mathrm{Zn}_{2}(\mathrm{OH})_{2} \mathrm{CO}_{3}$ suspension from seawater was carried out in the air and argon atmosphere. The stability of thiosulfate and sulfite in the filtrate of $2 \% \mathrm{NaCl}$ solutions was studied. It is important for estimating the storage time of samples before analysis. The time required for quantitative analysis and the limits of detection of sulfur forms are specified. Taking into account the experimental data, new results were obtained for the upper part of the anaerobic zone of the Black Sea.

\section{Methods of determination}

Data on the reduced species of sulfur in the Black Sea water were obtained at Ashamba-7 and Ashamba-9 stations (July 9 and 13, 2016) with coordinates $44.489^{\circ} \mathrm{N}$ and $37.869^{\circ} \mathrm{E}$ to the $320 \mathrm{~m}$ depth (potential density was $16.78 \mathrm{~kg} / \mathrm{m}^{3}$ ). Hydrophysical measurements were carried out by Sea-Bird SBE 19plus CTD. 
Sampling was carried out by Rosette complex, equipped with six 4-liter Niskin bottles. The hydrogen sulfide content was determined by the spectrophotometric method [17].

Flow chart of the method for determining the sum of sulfite and thiosulfate, the sum of zero-valent sulfur and sulfur polysulfides, and sulfide is shown in Fig. 1. The method of preparation of reagents and the sequence of operations are described in $[14,15]$ and have not practically been changed. The seawater volume for the analysis of thiosulfate and sulfite was $200 \mathrm{ml}$, except for experiments with $2 \% \mathrm{NaCl}$ solution $(60$ or $100 \mathrm{ml})$. The seawater volume for the analysis of zerovalent sulfur was usually about $500 \mathrm{ml}$. The $\mathrm{Zn}_{2}(\mathrm{OH})_{2} \mathrm{CO}_{3}$ suspension in the sample was always coagulated during 1 hour. All filtration operations were carried out on the Millipore filtration system (the Durapore membrane filter, pore size $0.45 \mu \mathrm{m} H V$ and diameter $47 \mathrm{~mm}$ ). Filtration was carried out either in the air or in a high purity argon atmosphere $(99.998 \%)$. The filtrate or filter (depending on the type of sulfur form detection) is introduced into a 350 or $500 \mathrm{ml}$ reaction flask filled with argon. After the sample introduction, it is continued to be flushed with argon for 5 minutes. In the case of determining the sum of sulfite and thiosulfate, $15 \mathrm{ml}$ of $12 \mathrm{~N} \mathrm{HCl}$ and $30 \mathrm{ml}$ of $1 \mathrm{M} \mathrm{CrCl}_{2}$ are added to the filtrate. The solution is heated to boiling, achieving a constant argon flow (80-90 bubbles in the absorber, which is filled with $\mathrm{Zn}$ acetate $(20 \mathrm{ml})$ ) (Fig. 2).

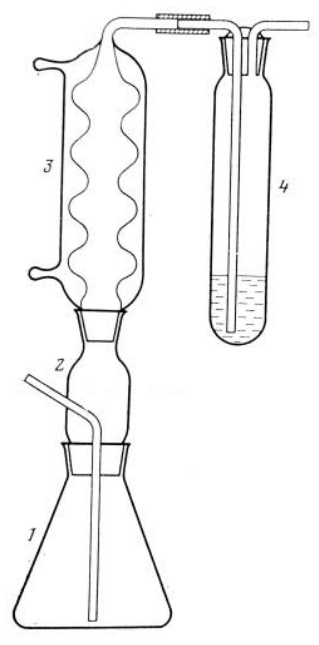

F i g. 2. Device for determining the reduced sulfur species: 1 - reaction flask (300 or $500 \mathrm{ml}) ; 2$ adaptor with a gasstreaming pipe filled with Ar; 3 - backflow condenser; 4 - test-tube absorbing $\mathrm{H}_{2} \mathrm{~S}$. Modified version of the figure from [14, p. 583]
The distillation time after the start of boiling is always 30 minutes. This reaction time was found empirically, so the $\mathrm{H}_{2} \mathrm{~S}$ absorbers are changed every 30 minutes. The first absorber is used to determine the sum of thiosulfate and sulfite (the analysis results are recalculated for thiosulfate only). In the second one, the complete distillation and the magnitude of the blank experiment are determined. Completeness of the analysis (distillation) was estimated by the value of ratio (in \%) between introduced and obtained analyte amount in the analysis . In quantitative analysis, it should be close to $100 \%$. The yield depends on the distillation time; it turned out to be close to $100 \%$ at a distillation time of 30 minutes. This parameter is checked by varying the distillation time with a change of the absorber after a certain time.

The determination of sulfide and zero-valent sulfur is carried out from a precipitation on a filter, which is placed in a reaction flask flushed with argon (Fig. 2). After placing the sample, $30 \mathrm{ml}$ of $6 \mathrm{~N} \mathrm{HCl}$ is added, the solution with the precipitation is heated to boiling in a stream of argon. Distillation after the heating termination lasts 30 minutes. 
. After the change of the first absorber, in which the sulfide is determined, in the second absorber the complete removal of hydrogen sulfide is controlled. Then $30 \mathrm{ml}$ of $1 \mathrm{M} \mathrm{CrCl}_{2}$ are added to the same flask.

After the start of boiling the distillation takes 30 minutes without heating. In the third absorber, the zero-valent sulfur content is obtained, and in the next one, after the change, in the fourth - the complete distillation and the experimental blank. Thus, hydrogen sulfide is absorbed by two absorbers with zinc acetate for 1 hour $(30+30 \mathrm{~min})$ during the distillation of filtrate. Four absorbers with zinc acetate are necessary for determination of sulfur species in precipitation, the duration is 2 hours. The detection limit is calculated as three standard deviations from the mean value for the blank experiment.

\section{Results and their discussion}

Determination of the stability of thiosulfate and sulfite in the filtrate after removal of zinc hydroxocarbonate suspension

To separate the sulfur forms, the $\mathrm{Zn}_{2}(\mathrm{OH})_{2} \mathrm{CO}_{3}$ suspension mixed with glycerol is used [13]. Glycerol in the suspension contributes to the sulfite stability in solution. In the method [14, 15], it is assumed that the analysis should be carried out immediately after sampling water from the Niskin bottles, which is not always possible. To determine the stability limits of thiosulfate and sulfite in solution, a series of experiments were carried using $2 \% \mathrm{NaCl}$ solutions prepared in oxygen-free water. The amount of salt in $2 \% \mathrm{NaCl}$ solution approximately corresponds to the salt (electrolyte) content in the Black Sea water. A similar concentration of electrolyte in the $2 \% \mathrm{NaCl}$ solution and in Black Sea water leads to the same conditions for coagulation of zinc hydroxocarbonate. This factor determines the sample filtration time and the amount of colloidal particles entering the filtrate. The use of $\mathrm{NaCl}$ solutions instead of seawater is associated with the possible presence of thiosulfate and sulfite in seawater.

After filtration under an argon atmosphere, a series of $100 \mathrm{ml}$ samples (from 5 to 9) were taken from the filtrate. One of the samples was used to determine oxygen by the Winkler Method [18], the rest were analyzed to determine the forms of sulfur at certain time intervals. When storing a thiosulfate solution (concentration from 2.20 to $2.45 \mu \mathrm{M}$ ) in a closed polyethylene bottle at $+4{ }^{\circ} \mathrm{C}$ in the dark place for 67 days, the thiosulfate content was not less than $98 \%$ of the introduced (Fig. 3). The experiments on the stability of sulfite were similarly carried out. In the first series, the output of sulfite with the initial content of 4.10$4.65 \mu \mathrm{M}$ ranged from $86 \%$ on the first day to $76 \%$ after 30 days of the experiment. In the second series with a higher oxygen content, the yield of sulfite was from $82 \%$ at the beginning of the experiment to $27 \%$ on the 62 nd day (Fig. 3). Experiments have shown high stability of thiosulfate in solutions and preservation up to $90 \%$ of sulfite for at least three days of storage of solutions. 


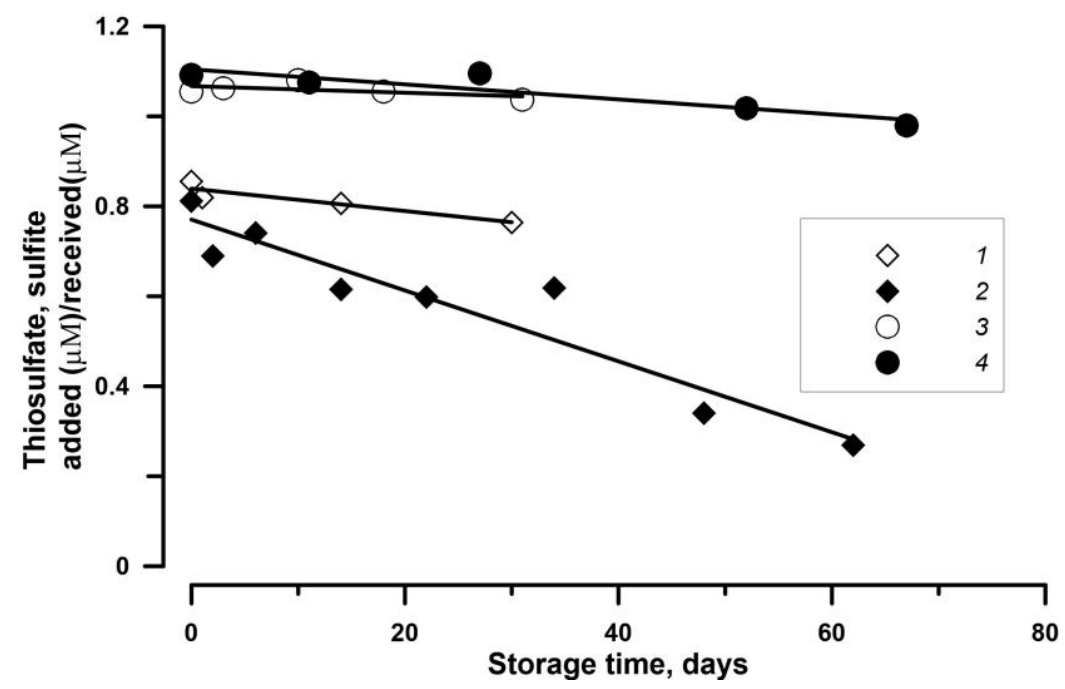

F i g. 3. Change of concentration of $\mathrm{Na}_{2} \mathrm{SO}_{3}(\sim 5 \mu \mathrm{M})(1,2)$ and $\mathrm{Na}_{2} \mathrm{~S}_{2} \mathrm{O}_{3}(\sim 2.5 \mu \mathrm{M})(3,4)$ in the filtrate of the $2 \%$-solution of $\mathrm{NaCl}$ after filtering the $\mathrm{Zn}_{2}(\mathrm{OH})_{2} \mathrm{CO}_{3}$ suspension at different initial concentrations of the dissolved oxygen: $1-58 \mu \mathrm{M} ; 2-87 \mu \mathrm{M} ; 3-51 \mu \mathrm{M} ; 4-135 \mu \mathrm{M}$

Determination of thiosulfate in the presence of large amount of hydrogen sulfide

The previously recommended time for analyzing one form of sulfur was 20-25 minutes $[14,15]$. We increased the analysis time to 30 minutes based on the experimentally established duration of achieving its completeness. The assessment of the completeness of the determination of sulfur forms, the accuracy and detection limit was carried out in the $2 \% \mathrm{NaCl}$ solution, adding $10 \mathrm{ml}$ of $\mathrm{Zn}_{2}(\mathrm{OH})_{2} \mathrm{CO}_{3}$ suspension and solutions of zero-valent sulfur, thiosulfate, sulfite and sodium sulfide of known concentrations.

Table 1

Variation of the sulfur species content in the process of the hydrogen sulfide oxidation, $\mu \mathrm{g} S$

\begin{tabular}{|c|c|c|c|c|c|c|c|c|c|}
\hline \multirow{4}{*}{$\begin{array}{l}\text { Time of the } \\
\text { samples } \\
\text { preparation } \\
\text { (analysis), day }\end{array}$} & \multicolumn{4}{|c|}{ In filtrate } & \multicolumn{4}{|c|}{ In sediment on the filter } & \multirow{4}{*}{$\begin{array}{l}\text { Total content } \\
\text { (sulfur yield) } \\
\text { with the } \\
\text { subtracted } \\
\text { blanks }\end{array}$} \\
\hline & \multicolumn{8}{|c|}{ Absorbers } & \\
\hline & 1 & 2 & 3 & 4 & 1 & 2 & 3 & 4 & \\
\hline & $\mathrm{H}_{2} \mathrm{~S}$ & blank & $\mathrm{S}_{2} \mathrm{O}_{3}$ & blank & $\mathrm{H}_{2} \mathrm{~S}$ & blank & $\mathrm{S}^{0}$ & blank & \\
\hline $0(1)$ & 1.3 & 0.1 & 9.4 & 0.4 & 1869 & 6.3 & 2.5 & 0.3 & $1875(1.03)$ \\
\hline $0(3)$ & 1.0 & 0.1 & 9.5 & 0.7 & 1868 & 2.9 & 2.5 & 0.2 & $1877(1.03)$ \\
\hline $0(6)$ & 1.6 & 0.1 & 11.0 & 0.7 & 1894 & 5.9 & 1.8 & 0.2 & $1901(1.05)$ \\
\hline $3(3)$ & 10.9 & 0.7 & 120.0 & 3.4 & 1602 & 6.9 & 9.4 & 0.3 & $1731(0.95)$ \\
\hline $7(7)$ & 27.9 & 1.4 & 305.0 & 4.4 & 1083 & 0.8 & 12.2 & 0.4 & $1420(0.78)$ \\
\hline $21(21)$ & 33.3 & 2.7 & 451.0 & 7.0 & 775 & 0.3 & 12.7 & 0.2 & $1261(0.69)$ \\
\hline $35(35)$ & 26.3 & 1.9 & 433.0 & 4.1 & 574 & 0.3 & 28.9 & 0.2 & $1056(0.58)$ \\
\hline
\end{tabular}

Note. The hydrogen sulfide initial content in the $2 \%$-solution of $\mathrm{NaCl}$ equals $1818 \mu \mathrm{g} \mathrm{S}(56.8 \mu \mathrm{mol}$ $\mathrm{H}_{2} \mathrm{~S}$ ). Total content is obtained after subtracting the blank experiments. 
Separation of sulfur forms by the filtration method can cause a noticeable penetration of sulfides into the filtrate with insufficient coagulation of the $\mathrm{Zn}_{2}(\mathrm{OH})_{2} \mathrm{CO}_{3}$ suspension. According to the method (Fig. 1), these sulfides are defined as thiosulfate and sulfite. To find out the degree of interfering influence of sulfides, the method of analyzing of sulfur species was applied to the sodium sulfide solution. Samples were taken from the $\mathrm{Na}_{2} \mathrm{~S}$ solution during its storage in a glass flask at $\mathrm{t}=22{ }^{\circ} \mathrm{C}$ for 35 days (Tab. 1). An aliquot $(1 \mathrm{ml})$ with $\mathrm{H}_{2} \mathrm{~S}$ concentration of about $60 \mu \mathrm{mol}$ was introduced into $2 \% \mathrm{NaCl}$ solution. Then the $\mathrm{Zn}_{2}(\mathrm{OH})_{2} \mathrm{CO}_{3}$ suspension $(10 \mathrm{ml})$ was added to this solution. Before the analysis the samples were stored in the dark place at $\mathrm{t}=+4{ }^{\circ} \mathrm{C}$. The first sample was filtered every other day, the resulting filtrate $(<0.45 \mu \mathrm{m})$ and the filter with the precipitation were analyzed each using four absorbers. These absorbers were changed every 30 minutes of the hydrogen sulfide distillation. Before the first absorber, $15 \mathrm{ml}$ of $6 \mathrm{~N} \mathrm{HCl}$ was added to the sample, before the third one $-15 \mathrm{ml}$ of $12 \mathrm{~N} \mathrm{HCl}$ and $30 \mathrm{ml}$ of $1 \mathrm{M} \mathrm{CrCl}_{2}$. According to the method (Fig. 1), $15 \mathrm{ml}$ of $6 \mathrm{~N} \mathrm{HCl}$ is not added to the filtrate. However, in the experiment we were interested in the amount of hydrogen sulfide that is released without reducing $\mathrm{CrCl}_{2}$ and corresponds to the $\mathrm{ZnS}$ fraction that passed through the $0.45 \mu \mathrm{m}$ filter. The second sample was analyzed after 3 days, the third one - after 6 days. In all three samples, only sulfide was identified (absorber 1, filter with precipitation). In the filtrate (absorber 1), the sulfide form of sulfur is lower than the detection limit. This indicates the completeness of the transfer of hydrogen sulfide to the precipitation (absorber 1) (Table 1). As the hydrogen sulfide is oxidizing, the amount of other reduced species of sulfur - the sum of thiosulfates and sulfites (absorber 3, filtrate) and zero-valent sulfur (absorber 3, precipitation) increased. A decrease in the $\mathrm{H}_{2} \mathrm{~S}$ concentration in the solution leads to a decrease in its trace amounts (absorber 2, precipitation, to $6.9 \mu \mathrm{g}$ of sulfur). These traces of hydrogen sulfide could have been previously interpreted as elemental sulfur.

The appearance of hydrogen sulfide while treating the filtrate with $6 \mathrm{~N} \mathrm{HCl}$ without a reducing agent may be associated with the decomposition of thiosulfate when boiling into hydrogen sulfide and tetrathionate [19]:

$$
9 \mathrm{H}_{2} \mathrm{~S}_{2} \mathrm{O}_{3} \rightarrow 2 \mathrm{H}_{2} \mathrm{~S}+4 \mathrm{H}_{2} \mathrm{~S}_{4} \mathrm{O}_{6}+3 \mathrm{H}_{2} \mathrm{O} .
$$




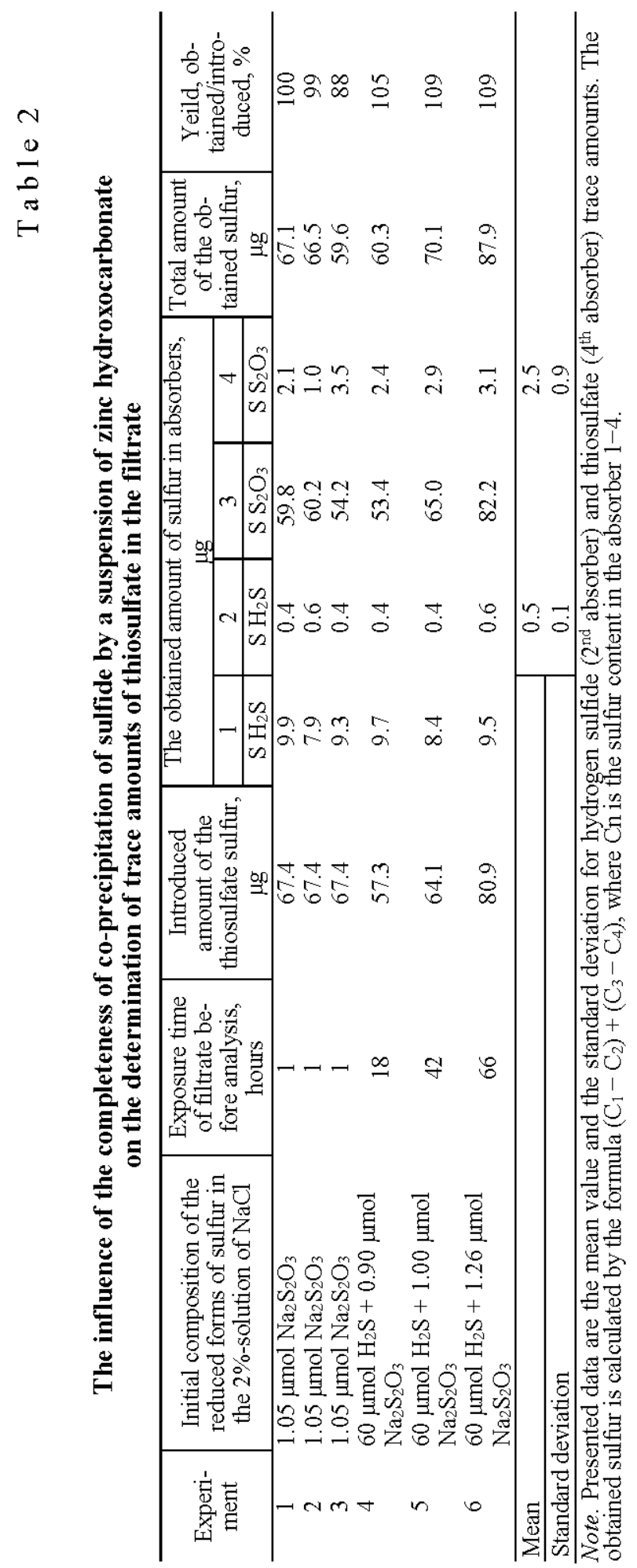


To confirm this conclusion, the filtrate of $2 \% \mathrm{NaCl}$ solution containing $\mathrm{S}_{2} \mathrm{O}_{3}$ in an amount close to its concentration in the Black Sea water (about $1 \mu \mathrm{mol}$ ) was distilled off using four absorbers (Tabl. 2). Hydrogen sulfide in the first three experiments was not introduced. As a result, it was shown that hydrogen sulfide appears in the first absorber in an amount approximately equal to the theoretical ratio of sulfur in hydrogen sulfide to sulfur in thiosulfate $-1 / 9$. Addition of hydrogen sulfide to the system (experiments 4-6) did not change this ratio (Tab. 2). The detection limit of hydrogen sulfide was $0.03 \mu \mathrm{mol}$ and the one of thiosulfate $0.05 \mu \mathrm{mol}$. In seawater samples, when, according to the method (Fig. 1), the determination of sulfide sulfur in the filtrate is not carried out, the detection limit was $0.03 \mu \mathrm{M}$ per thiosulfate. Experiments have shown that $\mathrm{H}_{2} \mathrm{~S}$ is effectively removed into the precipitation with zinc hydroxocarbonate in the form of $\mathrm{ZnS}$. Taking into account the blank experiments in absorbers 2 and 4 (Tab. 2), the yield of $\mathrm{S}_{2} \mathrm{O}_{3}$ was $88-109 \%$.

\section{Determination of the accuracy of elemental sulfur analysis}

In the works devoted to the method [1, 14 and 15], there is no data on the verification of the method for determining zero-valent sulfur. Its accuracy was checked, and the limit of zero-valent sulfur detection in $2 \% \mathrm{NaCl}$ solution was determined. The reagent blank $\left(0.002 \mu \mathrm{mol}\left(\mathrm{H}_{2} \mathrm{~S}\right)\right.$ and $\left.0.004 \mu \mathrm{mol}\left(\mathrm{S}^{0}\right)\right)$ turned out to be an order of magnitude below the detection limit (Tabel 3). Zero-valent sulfur was dissolved in acetone $(1 \mu \mathrm{mol} / \mathrm{ml})$. Then $1 \mathrm{ml}$ of the sulfur solution in acetone was added into $2 \% \mathrm{NaCl}$ solution. After adding the $\mathrm{Zn}_{2}(\mathrm{OH})_{2} \mathrm{CO}_{3}$ suspension, the solution was kept for $1 \mathrm{~h}$ prior to the filtration procedure $(0.45 \mu \mathrm{m})$. Zero-valent sulfur was determined in the filtrate and on the filter after heating to boiling with $1 \mathrm{M} \mathrm{CrCl}_{2}$ and $12 \mathrm{~N} \mathrm{HCl}$. About $0.1 \mu \mathrm{mol}$ of sulfur remained in the filtrate, which accounted for approximately $20 \%$ of the added concentrations (Fig. 4). The remaining sulfur was found on the filter (approximately 80\%), the deviation of the amount of suspended and dissolved sulfur from the added one did not exceed $10 \%$ (Tab.3). 
Results of determining the elemental sulfur, $\mu \mathrm{mol}$, obtained for filtrate and precipitation on the filter after filtering suspension of the zinc hydroxocarbonate in the $2 \% \mathrm{NaCl}$ solution

\begin{tabular}{|c|c|c|c|c|c|c|c|}
\hline \multirow{4}{*}{ Experiment } & \multirow{4}{*}{ Added sulfur } & \multicolumn{4}{|c|}{ Sulfur concentration } & \multirow{4}{*}{$\begin{array}{l}\text { the } \\
\text { obtained } \\
\text { sulfur }\end{array}$} & \multirow{4}{*}{$\begin{array}{c}\text { Deviation, } \\
\%\end{array}$} \\
\hline & & \multicolumn{2}{|c|}{ in filtrate } & \multicolumn{2}{|c|}{$\begin{array}{l}\text { in precipitation on the } \\
\text { filter }\end{array}$} & & \\
\hline & & \multicolumn{4}{|c|}{ Absorbers } & & \\
\hline & & 1 & 2 & 1 & 2 & & \\
\hline \multirow[t]{2}{*}{1} & 0.55 & 0.117 & 0.002 & 0.432 & 0.008 & 0.55 & 0.3 \\
\hline & 0.46 & 0.106 & 0.001 & 0.347 & 0.005 & 0,45 & -1.6 \\
\hline 3 & 0.66 & 0.148 & 0.003 & 0.572 & 0.009 & 0.72 & 9.9 \\
\hline 4 & 0.64 & 0.126 & 0.004 & 0.549 & 0.011 & 0.67 & 4.7 \\
\hline 5 & 0.38 & 0.104 & 0.003 & 0.245 & 0.009 & 0.35 & -8.1 \\
\hline 6 & 0.61 & 0.128 & 0.002 & 0.525 & 0.007 & 0.65 & 7.3 \\
\hline \multicolumn{2}{|l|}{ Mean } & - & 0.003 & - & 0.008 & - & - \\
\hline \multicolumn{2}{|c|}{ Standard deviation } & - & 0.001 & - & 0.002 & - & - \\
\hline \multicolumn{2}{|c|}{ Limit of determination } & - & 0.009 & - & 0.027 & - & - \\
\hline
\end{tabular}

Note. Solution and precipitation were analyzed for two absorbers: the $1^{\text {st }}-30 \mathrm{~min}$, the $2^{\text {nd }}-30 \mathrm{~min}$.

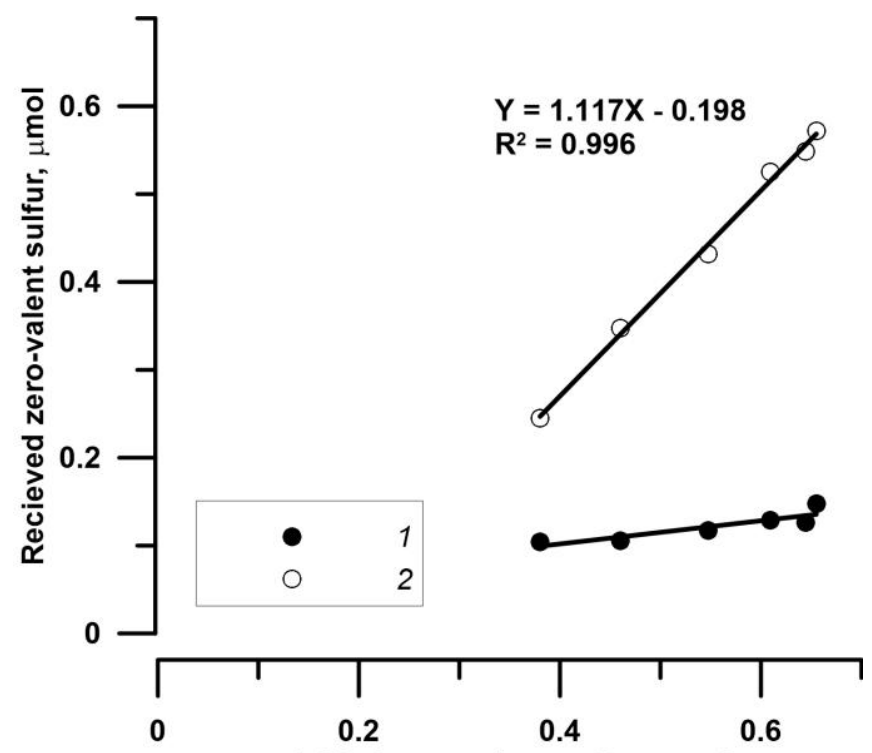

Added zero-valent sulfur, $\mu \mathrm{mol}$

F i g. 4. Determination of zero-valent sulfur in the $2 \%$-solution of $\mathrm{NaCl}$ : 1 -filtrate, 2 - precipitation 
Effect of filling the Niskin bottles with argon on the concentration of hydrogen sulfide, thiosulfate and zero-valent sulfur

The method for the determination of reduced forms of sulfur [14, 15] provided for the filling of chemical glasswere before analysis with argon to prevent oxidation of samples. Water sampling from the Niskin bottle when filling it with argon for this type of analysis was not previously carried out. The subsequent operation of $\mathrm{Zn}_{2}(\mathrm{OH})_{2} \mathrm{CO}_{3}$ suspension filtering in the air could lead to oxidation of the reduced forms of sulfur in the sample. Filling of the Niskin bottles with argon $[17,20]$ showed that at the low $\mathrm{H}_{2} \mathrm{~S}$ concentration the sensitivity of the determination method $(0.3 \mu \mathrm{M})$ is not enough to assess the effect of atmospheric oxygen on the hydrogen sulfide content in water. At the same time, the amount of oxygen to be determined in the suboxic layer depends significantly on the filling of Niskin bottles on shipboard with inert gas [21].

At the Ashamba-7 station, two Niskin bottles were closed on each of eight depths, conducting sampling when filled with argon and the air, respectively. Water for determining the forms of sulfur were sampled in closed bottles (volume $1.0 \mathrm{l}$ ), which $\mathrm{Zn}_{2}(\mathrm{OH})_{2} \mathrm{CO}_{3}$ suspension was added on the shore in advance. Then they were filled with argon. Samples taken from the Niskin bottle when it was filled with argon or the air were filtered, in the argon or air atmosphere, respectively.

Data for hydrogen sulfide, obtained by sampling in two ways, are given in Tab. 4 and Fig. 5. On Fig. 5 it can be seen that the air oxygen does not affect the $\mathrm{H}_{2} \mathrm{~S}$ content within the sensitivity limits of the applied method of analysis $(0.3 \mu \mathrm{M})$ [17]. A different result was obtained for thiosulfate (Fig. 6a). Obviously, the data on the concentration of thiosulfate and sulfite, obtained without filling the Niskin bottle with argon, is higher when the $\mathrm{H}_{2} \mathrm{~S}$ content is greater than $9 \mu \mathrm{M}$ (Tab. 4). When water is taken from the Niskin bottle, $\mathrm{H}_{2} \mathrm{~S}$ is partially oxidized. When the hydrogen sulfide concentration is $74 \mu \mathrm{M}$, the addition reaches $65 \%$ (Tab.4). The effect of the sampling method from the Niskin bottle on the concentrations of zero-valent sulfur is significantly less (Fig. 6b), the differences between the contents are within the limits of the analytical error (Tab. 4).

Table 4

Effect of filling the Niskin bottles with argon and air during water sampling upon determining the reduced species of sulfur (hydrogen sulfide, thiosulfate, zerovalent sulfur), $\mu \mathrm{mol}$, in the Black Sea water at the Ashamba-7 station (09.07.2016)

\begin{tabular}{|c|c|c|c|c|c|c|c|c|c|c|}
\hline \multirow{3}{*}{ Depth, m } & \multirow{3}{*}{$t,{ }^{\circ} \mathrm{C}^{1}$} & \multirow{3}{*}{$\theta,{ }^{\circ} \mathrm{C}^{2}$} & \multirow{3}{*}{$\begin{array}{l}\text { Salinity, } \\
\text { psu }\end{array}$} & \multirow{3}{*}{$\begin{array}{c}\text { Density, } \\
\mathrm{kg} / \mathrm{m}^{3}\end{array}$} & \multicolumn{6}{|c|}{ Content of the sulfur species during filling with } \\
\hline & & & & & \multicolumn{3}{|c|}{ argon } & \multicolumn{3}{|c|}{ air } \\
\hline & & & & & $\mathrm{H}_{2} \mathrm{~S}$ & $\mathrm{~S}^{0}$ & $\mathrm{~S}_{2} \mathrm{O}_{3}$ & $\mathrm{H}_{2} \mathrm{~S}$ & $\mathrm{~S}^{0}$ & $\mathrm{~S}_{2} \mathrm{O}_{3}$ \\
\hline 150 & 8.65 & 8.64 & 20.71 & 16.00 & $<0.01$ & $\mathrm{nd}^{3}$ & но / nd & $<0.01$ & nd & nd \\
\hline 160 & $8, .8$ & 8.67 & 20.88 & 16.12 & $<0.01$ & nd & но / nd & $<0.01$ & nd & nd \\
\hline 166 & 8.69 & 8.68 & 20.93 & 16.16 & 0.12 & 0.03 & 0.04 & 0.26 & 0.03 & 0.03 \\
\hline 175 & 8.67 & 8.66 & 21.02 & 16.24 & 7.07 & 0.09 & 0.04 & 6.86 & 0.09 & 0.04 \\
\hline 180 & 8.67 & 8.65 & 21.05 & 16.26 & 7.70 & 0.11 & 0.05 & 7.50 & 0.10 & 0.04 \\
\hline 190 & 8.67 & 8.66 & 21.14 & 16.34 & 11.9 & 0.11 & 0.03 & 12.1 & 0.12 & 0.06 \\
\hline 200 & 8.68 & 8.67 & 21.21 & 16.39 & 17.4 & 0.17 & 0.05 & 16.8 & 0.12 & 0.07 \\
\hline 250 & 8.76 & 8.73 & 21.50 & 16.61 & 43.6 & 0.23 & 0.08 & 43.1 & 0.19 & 0.13 \\
\hline 280 & 8.79 & 8.77 & 21.62 & 16.69 & 57.0 & 0.26 & 0.07 & 58.7 & 0.30 & 0.22 \\
\hline 320 & 8.82 & 8.80 & 21.73 & 16.78 & 74.1 & 0.29 & 0.15 & 73.6 & 0.33 & 0.45 \\
\hline
\end{tabular}

1 - temperature

2 - potential temperature

${ }^{3}$ - no determined

PHYSICAL OCEANOGRAPHY VOL. 26 ISS. 12019 


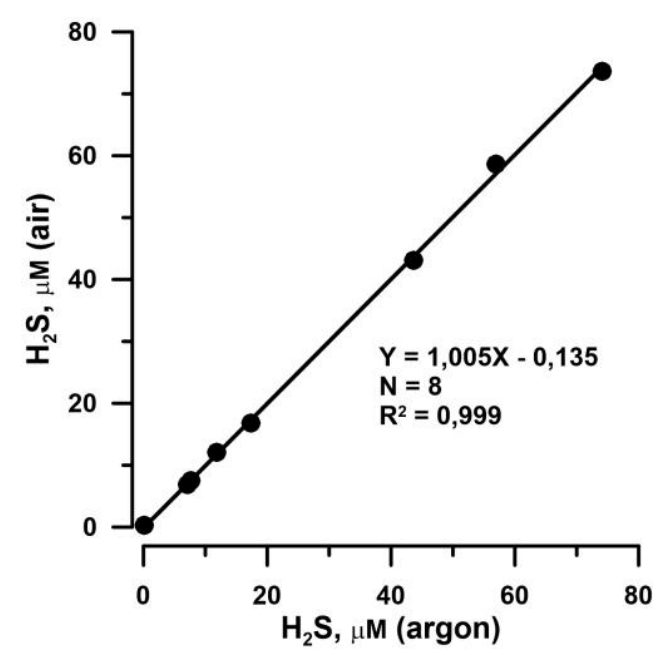

F i g. 5. Comparison of the hydrogen sulfide concentration $(\mu \mathrm{M})$ in the simultaneously closed Niskin bottles filled with air and argon during sampling
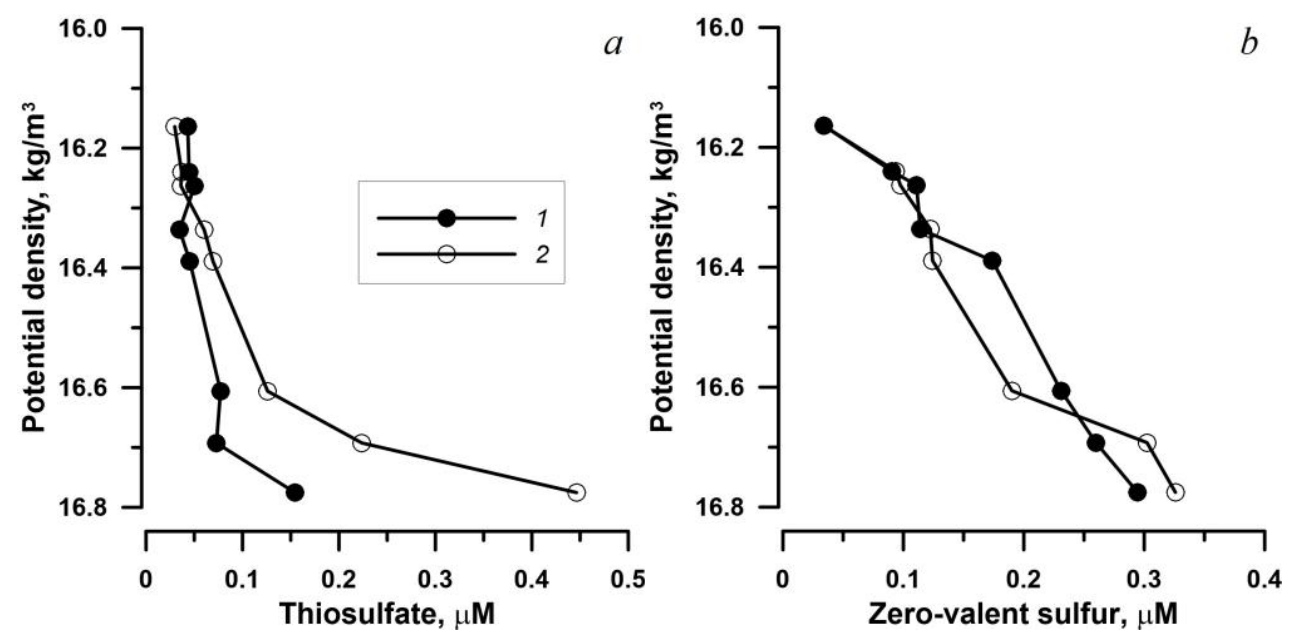

F i g. 6. Comparison of the thiosulfate $(a)$ and zero-valent sulfur $(b)$ concentrations in the simultaneously closed Niskin bottles filled with argon (1) and air (2) during sampling

Filtration of samples with $\mathrm{Zn}_{2}(\mathrm{OH})_{2} \mathrm{CO}_{3}$ suspension in the air can lead to the oxidation of reduced forms of sulfur. At the Ashamba-9 station, all samples were taken from the Niskin bottles using argon to fill them (Tab. 5). The samples were filtered in an argon atmosphere, and three of them - additionally in air. No significant differences in the data on the thiosulfate concentrations in samples filtered in an atmosphere of argon and air were found. Zero-valent sulfur data during filtration in air turned out to be systematically lower than the results obtained during filtration in an argon atmosphere (Tab. 5). The resulting systematic error may indicate the oxidation of sulfur during filtration in air. These results do not contradict the zero-valent sulfur data given in Tab. 4 and Fig. 6b. Air filling of 
the Niskin bottles leads to the oxidation of part of $\mathrm{H}_{2} \mathrm{~S}$ and the appearance of the newly formed $S^{0}$. During the filtration procedure, partial oxidation of $S^{0}$ takes place.

Table 5

Concentrations of the reduced sulfur species (hydrogen sulfide, thiosulfate, zerovalent sulfur), $\mu M$, in the Black Sea water at the Ashamba-9 station (13.07.2016)

\begin{tabular}{cccccccccc}
\hline Depth, $\mathrm{m}$ & $t,{ }^{\circ} \mathrm{C}^{1}$ & $\theta,{ }^{\circ} \mathrm{C}^{2}$ & Salinity, psu & $\begin{array}{c}\text { Density, } \\
\mathrm{kg} / \mathrm{m}^{3}\end{array}$ & $\mathrm{H}_{2} \mathrm{~S}$ & $\mathrm{~S}_{2} \mathrm{O}_{3}$ & $\mathrm{~S}^{0}$ \\
\hline 145 & 8.66 & 8.65 & 20.70 & 15.99 & $<0.01$ & $<0.03$ & 0.03 \\
156 & 8.67 & 8.66 & 20.88 & 16.13 & $<0.01$ & 0.06 & $<0.02$ \\
159 & 8.65 & 8.64 & 20.92 & 16.16 & $<0.01$ & 0.06 & $<0.02$ \\
164 & 8.66 & 8.64 & 20.95 & 16.18 & 0.31 & 0.06 & 0.03 \\
170 & 8.65 & 8.63 & 21.01 & 16.23 & 4.61 & $0.03(0.04)^{3}$ & $0.10(0,06)$ \\
181 & 8.66 & 8.65 & 21.13 & 16.33 & 12.7 & $<0.03$ & 0.09 \\
202 & 8.70 & 8.68 & 21.30 & 16.45 & 24.4 & 0.06 & 0.16 \\
230 & 8.75 & 8.73 & 21.48 & 16.59 & 38.0 & $0.07(0.06)$ & $0.19(0.16)$ \\
250 & 8.77 & 8.75 & 21.55 & 16.64 & 46.4 & 0.09 & 0.25 \\
280 & 8.80 & 8.77 & 21.64 & 16.71 & 57.8 & 0.08 & 0.28 \\
300 & 8.82 & 8.79 & 21.70 & 16.76 & 71.4 & $\mathrm{nd}^{4}$ & 0.42 \\
321 & 8.83 & 8.80 & 21.75 & 16.79 & 75.5 & $0.10(0.13)$ & $0.34(0.25)$ \\
\hline
\end{tabular}

1 - temperature

2 - potential temperature

${ }^{3}$ - the results in brackets are obtained after filtering in the air

${ }^{4}$ - no determined

Based on the analysis of samples of blank experiments, the detection limits were calculated. The detection limit for $\mathrm{H}_{2} \mathrm{~S}$ and $\mathrm{S}^{0}$, calculated as the sum of the mean and three standard deviations, was 0.01 and $0.02 \mu \mathrm{M}$, respectively. The detection limit $\left(\mathrm{S}_{2} \mathrm{O}_{3}+\mathrm{SO}_{3}\right)$ is $0.03 \mu \mathrm{M}$.

\section{Conclusion}

This research showed that the method for determining the reduced sulfur species, proposed in [14, 15], has good sensitivity for the sum of the forms $\left(\mathrm{S}_{2} \mathrm{O}_{3}^{2-}+\mathrm{SO}_{3}^{2-}\right)$ and $\left(\mathrm{S}^{0}+\mathrm{S}^{0}\right.$ polysulfides $)$. The detection limit for the sum of thiosulfates and sulfites $\left(\mathrm{S}_{2} \mathrm{O}_{3}^{2-}+\mathrm{SO}_{3}^{2-}\right)$, defined as the sum of the mean value and the three standard deviations for blank experiments in the analysis of seawater, was $0.03 \mu \mathrm{M}$, and for the sum of elemental sulfur and sulfur polysulfides $\left(\mathrm{S}^{0}+\mathrm{S}^{0}\right.$ polysulfides $)-0.02 \mu \mathrm{M}$. The detection limit of $\mathrm{H}_{2} \mathrm{~S}$ is $0.01 \mu \mathrm{M}$, which is 30 times better than the result obtained using the standard spectrophotometric method for the $\mathrm{H}_{2} \mathrm{~S}$ determination in seawater [17].

The accuracy of the method and measurement results was verified using $2 \% \mathrm{NaCl}$ solutions with introduced concentrations of thiosulfate $(0.5-1.5 \mu \mathrm{mol})$, sulfite $(1 \mu \mathrm{mol})$, zero-valent sulfur (up to $1 \mu \mathrm{mol}$ ) against the background of much higher hydrogen sulfide concentrations $(60 \mu \mathrm{mol})$. The selection of the concentrations corresponds to the ratio of these sulfur species in the Black Sea 
water. It was shown that the presented method of analysis adequately reflects the presence of these forms in solutions, and a large amount of $\mathrm{H}_{2} \mathrm{~S}$ is effectively removed into the precipitation by $\mathrm{Zn}_{2}(\mathrm{OH})_{2} \mathrm{CO}_{3}$ suspension, without interfering the determination of trace amounts of other reduced sulfur species. To analyze them, it is necessary to fill the Niskin bottles with inert gas and filter in an inert atmosphere.

\section{REFERENCES}

1. Volkov, I.I., 1990. Elementnaya Sera v Vode Chernogo Morya [Elementary Sulfur in the Black Sea Water]. Doklady Akademii Nauk SSSR, 315(1), pp. 201-205 (in Russian).

2. Volkov, I.I., 1991. Soedineniya Vosstanovlennoy Sery v Vode Chernogo Morya [Reduced Sulfur Species in the Black Sea Water]. In: M. E. Vinogradov, ed., 1991. Izmenchivost' Ekosistemy Chernogo Morya: Estestvennye i Antropogennye Factory [Variability of the Black Sea ecosystem: Natural and Anthropogenic Factors]. Moscow: Nauka, pp. 53-72 (in Russian).

3. Luther III, G.W., Church, T.M. and Powell, D., 1991. Sulfur Speciation and Sulfide Oxidation in the Water Column of the Black Sea. Deep Sea Research Part A. Oceanographic Research Papers, [e-journal] 38(Suppl. 2), pp. S1121-S1137. https://doi.org/10.1016/S0198$0149(10) 80027-5$

4. Jørgensen, B.B., Fossing, H., Wirsen, C.O. and Jannasch, H.W., 1991. Sulfide Oxidation in the Anoxic Black Sea Chemocline. Deep Sea Research Part A. Oceanographic Research Papers, [e-journal] 38(Suppl. 2), pp. S1083-S1103. https://doi.org/10.1016/S01980149(10)80025-1

5. Valravamurthy, A. and Mopper, K., 1990. Determination of Sulfite and Thiosulfate in Aqueous Samples Including Anoxic Seawater by Liquid Chromatography after Derivatization with 2,2'-dithiobis (5-nitropyridine). Environmental Science \& Technology, [e-journal] 24(3), pp. 333-337. doi:10.1021/es00073a007

6. Zhang, J-Z. and Millero, F.J., 1993. The Chemistry of the Anoxic Waters in the Cariaco Trench. Deep Sea Research Part I: Oceanographic Research Papers, [e-journal] 40(5), pp. 1023-1041. https://doi.org/10.1016/0967-0637(93)90088-K

7. Hayes, M.K., Taylor, G.T., Astor, Y. and Scranton, M.I., 2006. Vertical Distribution of Thiosulfate and Sulfite in the Cariaco Basin. Limnology and Oceanography, [e-journal] 51(1), pp. 280-287. https://doi.org/10.4319/lo.2006.51.1.0280

8. Percy, D., Li, X., Taylor, G.T., Astor, Y. and Scranton, M.I., 2008. Controls on Iron, Manganese and Intermediate Oxidation State Sulfur Compounds in the Cariaco Basin. Marine Chemistry, [e-journal] 111(1-2), pp. 47-62. https://doi.org/10.1016/j.marchem.2007.02.001

9. Li, X., Taylor, G.T., Astor, Y. and Scranton, M.I., 2008. Relationship of Sulfur Speciation to Hydrographic Conditions and Chemoautotrophic Production in the Cariaco Basin Marine Chemistry, [e-journal] 112(1-2), pp. 53-64. https://doi.org/10.1016/j.marchem.2008.06.002

10. Zhang, J-Z. and Millero, F.J., 1993. The Products from the Oxidation of $\mathrm{H}_{2} \mathrm{~S}$ in Seawater. Geochimica Cosmochimica Acta, [e-journal] 57(8), pp. 1705-1718. https://doi.org/10.1016/0016-7037(93)90108-9

11. Konovalov, S.K., Luther III, G.W., Friederich, G.E., Nuzzio, D.B., Tebo, B.M., Murray, J.W., Oguz, T., Glazer, B., Trouwborst, R.E., Clement, B., Murray, K.J. and Romanov, A.S., 2003. Lateral Injection of Oxygen with the Bosporus Plum-Fingers of Oxidizing Potential in the Black Sea. Limnology and Oceanography, [e-journal] 48(6), pp. 2369-2376. https://doi.org/10.4319/lo.2003.48.6.2369

12. Skopintsev, B.A. and Gubin, F.A., 1955. Nekotorye Resultaty Gidrohimicheskih Issledovaniy v Chernom More v 1952-1953 Godah [Some Results of Hydrochemical Investigations in the Black Sea in 1952-1953]. In: Trudy Morskogo Gidrophizicheskogo Instituta AN SSSR [Proceedings of the Marine Hydrophysical Institute of AS USSR]. Moscow: AS USSR Publ. Vol. 5, pp. 71-98 (in Russian).

13. Volkov, I.I. and Ostroumov, E.A., 1957. Opredelenie Tiosulfatov v Ilovyh Vodah osadkov Chernogo Morya [Determination of Thiosulfates in Pore Waters of the Black Sea Sediments]. Doklady Akademii Nauk SSSR, 114(4), pp. 853-855 (in Russian). 
14. Volkov, I.I. and Zhabina, N.N., 1990. Opredelenie Tiosulfatov i Sulfitov v Morskoy Vode [Determination of Thisulfates and Sulfites in Sea Water]. Okeanologiya, 30(4), pp.582-587 (in Russian).

15. Volkov, I.I. and Zhabina, N.N., 1990. Metod Opredeleniya Vosstanovlennyh Soedineniy Sery $\mathrm{v}$ Morskoy Vode [Method of Determination of Reduced Sulfur Compounds in the Sea Water]. Okeanologiya, 30(5), pp. 778-782 (in Russian).

16. Neretin, L.N., Böttcher, M.E. and Grinenko, V.A., 2003. Sulfur Isotope Geochemistry of the Black Sea Water Column. Chemical Geology, [e-journal] 200(1-2), pp. 59-69. https://doi.org/10.1016/S0009-2541(03)00129-3

17. Dubinin, A.V., Demidova, T.P., Kremenetskii, V.V., Kokryatskaya, N.M., RimskayaKorsakova, M.N. and Yakushev, E.V., 2012. Determination of the reduced sulfur species in the anoxic zone of the Black Sea: A comparison of the spectrophotometry and iodometry techniques. Oceanology, [e-journal] 52(2), pp.181-190. doi:10.1134/S0001437012010080

18. Bordovskiy, O.K. and Chernyakov, A.M. eds., 1992. Sovremennye Metody Gidrohimicheskih Issledovaniy Okeana [Modern Methods of Ocean Hydrochemical Investigations]. Moscow: IO RAS, 199 p. (in Russian).

19. Volynskii, N.P., 1971. Tiosernaya Kislota. Politionaty. Reaktsiya Vakenrodera [Thiosulfuric Acid. Polythionates. Wakenroder Reaction]. Moscow: Nauka, 78 p. (in Russian).

20. Bezborodov, A.A., 1989. Tonkaya Geohimicheskaya Struktura Zony Vzaimodeystviya Aerobnyh i Anaerobnyh Vod v Chernom More [Fine Geochemical Structure of the Zone of Interaction between Aerobic and Anaerobic Waters in the Black Sea]. In: Kompleksnye Okeanograficheskie Issledovaniya Chernogo Morya [Complex Oceanographic Investigations of the Black Sea]. Sevastopol: MHI of USSR AS, pp. 131-152 (in Russian).

21. Yakushev, E.V., Vinogradova, E.L., Dubinin, A.V., Kostyleva, A.V., Men'shikova, N.M. and Pakhomova, S.V., 2012. On Determination of Low Oxygen Concentrations with Winkler Technique. Oceanology, [e-journal] 52(1), pp. 122-129. doi:10.1134/S0001437012010201

About the authors:

Alexandr V. Dubinin - Chief Research Associate, IO RAS (36 Nakhimovskiy Ave., Moscow, 117997, Russian Federation), Ag. Head of Laboratory, Dr.Sci. (Chem.), ResearcherID: F-9008-2014, e-mail: dubinin_av@mail.ru

Tatiyana P. Demidova - Research Associate, IO RAS (36 Nakhimovskiy Ave., Moscow, 117997, Russian Federation)

Mariya N. Rimskaya-Korsakova - Senior Research Associate, Laboratory of Geochemistry, IO RAS (36 Nakhimovskiy Ave., Moscow, Russian Federation, 117997), Ph.D. (Chemistry), ResearcherID: S-2127-2016, korsakova@ocean.ru

Lybov' S. Semilova - Laboratory Assistant - Laboratory of Geochemistry, IO RAS (36 Nakhimovskiy Ave., Moscow, Russian Federation, 117997), semilova.luybov@mail.ru

Oksana A. Ocherednik - Postgraduate, Junior Research Associate, Laboratory of Sea Chemistry, Southern Branch of IO RAS (1g Prostornaya St., Gelendzhik, Krasnodar Krai, 353467, Russian Federation), e-mail: ksushagub@gmail.com

Contribution of the co-authors:

Alexandr V. Dubinin - sampling, the idea of work, preparation of the manuscript

Tatiyana P. Demidova - sampling, carried out analysis of sulfur forms

Mariya N. Rimskaya-Korsakova - sampling, carried out analysis of forms of sulfur, preparation of the manuscript

Lybov' S. Semilova - sampling, filtration, carried out analysis of forms of sulfur

Oksana A. Ocherednik - sampling and filtering of samples

All the authors have read and approved the final manuscript.

The authors declare that they have no conflict of interest. 